\title{
ANALISIS PENDAPATAN USAHA PETERNAKAN ITIK PETELUR INTENSIF DI KABUPATEN PASURUAN
}

\author{
Revenue Analysis on Laying Ducks of Intensive System in The District of Pasuruan \\ Hariadi Subagja', Mohammad Hasan Basri' ${ }^{1}$, dan Rizki Amalia Nurfitriani ${ }^{2}$ \\ 1Program Studi Manajemen Bisnis Unggas, Jurusan Peternakan, Politeknik Negeri Jember \\ ${ }^{2}$ Program Studi Produksi Ternak, Jurusan Peternakan, Politeknik Negeri Jember \\ Email: hariadisubagja@gmail.com
}

\begin{abstract}
ABSTRAK
Tujuan penelitian ini yaitu untuk mengetahui besarnya pendapatan, Efisiensi usaha dan faktor pendapatan (Pakan, Tenaga Kerja, OVK, Skala Usaha, dan Pengalaman Beternak) terhadap pendapatan peternakan itik petelur sistem pemeliharaan intensif di Desa Kejapanan Kecamatan Gempol Kabupaten Pasuruan. Metode penelitian yang digunakan ialah metode survey dengan wawancara langsung kepada 30 peternak. Teknik analisis data yaitu dengan menghitung biaya, penerimaan, pendapatan dan efisiensi. Pendapatan tertinggi diperoleh oleh peternak yang mempunyai skala usaha 1000 ekor sebesar Rp. 7.581 .866 sedangkan pendapatan terendah diperoleh oleh peternak yang mempunyai skala usaha 100 ekor sebesar Rp. 267.459 yang diperoleh dalam satu bulan. $\mathrm{R} / \mathrm{C}$ ratio terendah 1,06 dengan skala usaha 150 ekor dan tertinggi 1,39 dengan skala usaha 550 ekor. ROI terendah 5,8 \% dengan skala usaha 150 ekor dan tertinggi 39 \% dengan skala usaha 550 ekor.
\end{abstract}

Kata kunci: Faktor Pendapatan, Intensif, Itik Petelur, Pendapatan Peternak

\section{ABSTRACT}

The purpose of this study was to determine the amount of income, efficiency and income factors (Feed, Labor, OVK, Scale of Business, and Length of Farming) on the income of intensive laying duck farming systems in the village of Kejapanan, Gempol District, Pasuruan Regency. The research method used was the survey method with direct interviews with 30 farmers. The research method used was the survey method with direct interviews with 30 farmers. The data analysis technique is to calculate costs, revenues, income and efficiency. The highest income is obtained by breeders who have a business scale of 1000 individuals in the amount of Rp. 7,581,866 while the lowest income is obtained by farmers who have a business scale of 100 individuals in the amount of Rp. 267,459 gained in one month. The lowest $R / C$ ratio is 1.06 with a business scale of 150 tails and the highest is 1.39 with a business scale of 550 tails. The lowest ROI is $5.8 \%$ with a business scale of 150 tails and the highest is $39 \%$ with a business scale of 550 tails.

Keywords: Income Factors, Intensive, Laying Ducks, Farmer Income

\section{PENDAHULUAN}

Usaha peternakan di Indonesia yang cukup berkembang di bidang perunggasan selain ayam ras adalah itik. Itik memiliki potensi yang cukup besar salah satunya sebagai penghasil telur atau disebut dengan itik petelur (Prasetyo, Ketaren \& Susanti, 2010). Itik memiliki kelebihan diantaranya yaitu memiliki daya tahan terhadap penyakit dibandingkan dengan unggas lain seperti ayam ras. Kuantitas produksi itik petelur menurut statistik Peternakan dan Kesehatan Hewan 2017, 
Provinsi Jawa Timur merupakan penyumbang terbesar ke 3 nasional setelah Jawa Barat dan Jawa Tengah dengan jumlah produksi pada tahun 2013 sebesar 26.590, pada tahun 2014 sebesar 32.132 ton, pada tahun 2015 sebesar 32.340 ton, sedangkan pada tahun 2016 terjadi peningkatan yang signifikan sebesar 36.184 ton, dan pada tahun 2017 meningkat menjadi 37.624 ton. Meningkatnya konsumsi telur itik dan populasi itik petelur dari tahun ke tahun disebabkan oleh kebutuhan dan permintaan masyarakat, maka dari itu dibutuhkan sistem pemeliharaan yang mampu meningkatkan kuantitas produksi itik petelur agar mampu memenuhi kebutuhan telur itik di Jawa Timur.

Sistem pemeliharaan usaha itik petelur yang digunakan yaitu sistem pemeliharaan intensif. Peternak itik petelur yang menggunakan sistem pemeliharaan intensif yaitu dengan cara itik ditempatkan di dalam kandang dan menggunakan pakan buatan bernutrisi yang diberikan secara teratur. Sistem pemeliharaan intensif menghasilkan produktifitas itik dengan pencapaian produksi rata-rata 230-250 butir/ekor/tahun atau memiliki prosentase sebanyak 70\%-80\%. Hal ini berbeda jika dibandingkan dengan pemeliharaan sistem tradisional yang mampu menghasilkan telur sebanyak 90-120 butir/ekor/tahun atau memiliki prosentase sebanyak 30\%-40\%. (Rasyaf, 1993).

Berdasarkan observasi dan survey awal, Desa Kejapanan merupakan sentra peternakan itik terbesar di Kecamatan Gempol Kabupaten Pasuruan. Masyarakat yang berada di Desa Kejapanan Kecamatan Gempol Kabupaten Pasuruan mayoritas memiliki pekerjaan sebagai pegawai dan karyawan perusahaan. Di samping itu, ada 30 peternak aktif yang menggunakan pemeliharaan itik petelur dengan sistem intensif dengan rata-rata skala usaha 100 hingga 1200 ekor. Skala usaha yang dilakukan oleh peternak tersebut sudah dijadikan sebagai usaha pokok. Akan tetapi, 30 peternak di Kecamatan Gempol Kabupaten Pasuruan tersebut belum mengetahui mengenai factor yang mempengaruhi pendapatan. Ketidaktahuan ini menjadi salah satu permasalahan terutama dalam menghitung pendapatan bersih peternak, dimana pendapatan merupakan hasil dari usaha yang telah dilakukan, sehingga penting untuk diketahui. Adapun factor yang mempengaruhi pendapatan yaitu pakan, tenaga kerja, OVK, skala usaha, pengalaman dalam beternak, serta pendapatan yang diperoleh dari usaha peternakan itik sistem pemeliharaan intensif.

Adanya permaslaahan tersebut perlu segara dicarikan solusi agar peternak dapat memahami dan menganalisis pendapatan usaha yang dilakukan. Salah satu solusi yang dapat dilalukan yaitu membuat analisis pendapatan usaha peternakan itik petelur dengan sistem pemeliharaan intensif di Desa Kejapanan Kecamatan Gempol Kabupaten Pasuruan. Tujuan dari penelitian ini adalah untuk mengetahui besarnya pendapatan, nilai R/C dan Return on Investment (ROI), serta peran factor pendapatan (biaya pakan, tenaga kerja, OVK, skala usaha, dan pengalaman beternak) yang berpengaruh terhadap pendapatan pada usaha peternakan itik petelur dengen sistem pemeliharaan intensif di Desa Kejapanan Kecamatan Gempol Kabupaten Pasuruan.

\section{METODE}

Rancangan penelitian ini merupakan jenis penelitian yang menggunakan analisis deskriptif kuantitatif. Analisis deskriptif yaitu jenis penelitian yang akan menggambarkan tentang tingkat pendapatan usaha peternakan itik petelur sistem pemeliharaan intensif di Desa Kejapanan Kecamatan Gempol Kabupaten Pasuruan. Analisis kuantitatif yaitu digunakan untuk mengetahui besarnya investasi, biaya produksi, penerimaan, pendapatan, dan tingkat efisiensi usaha peternakan itik petelur. Data yang terkumpul dianalisis dengan regresi linier berganda.

\section{Populasi dan Teknik Pengambilan Sampel}

Populasi dalam penelitian ini yaitu semua peternak itik petelur yang menggunakan sistem pemeliharaan secara intensif di Desa Kejapanan Kecamatan Gempol Kabupaten Pasuruan. Total 
peternak itik petelur sistem pemeliharaan intensif yang ada di Desa Kejapanan sebanyak 30 peternak. Metode sampling yang digunakan dalam penelitian ini yaitu purposive sampling yaitu teknik pengambilan sampel secara sengaja berdasarkan jumlah peternak dengan populasi 100-1200 ekor serta sudah beternak selama minimal 1 tahun atau 1 periode. Pada penelitian ini semua populasi dijadikan responden atau sampel sebanyak 30 peternak. Metode yang digunakan dalam pengambilan sampel yaitu survei. Pengumpulan data menggunakan data primer dan data sekunder. Data primer diperoleh langsung dari narasumber melalui wawancara mendalam (indepth interview) secara langsung dengan menggunakan pedoman wawancara, serta dengan menggunakan daftar pertanyaan (kuisioner) yang telah disiapkan sebelumnya, dan melakukan observasi ke daerah penelitian. Data sekunder diperoleh dari berbagai instansi dan lembaga pemerintah yang terkait dengan penelitian yang sedang dilakukan seperti Dinas Peternakan, Balai Penelitian Ternak, Direktorat Jendral Peternakan, serta Badan Pusat Statistik (BPS).

\section{Teknik Pengumpulan Data}

Teknik pengumpulan data dilakukan dengan menghitung total biaya, penerimaan, pendapatan, $\mathrm{R} / \mathrm{C}$ ratio, dan Return on Investment (ROI). Adapun rumus perhitungan Teknik pengumpulan data tersebut sebagai berikut:

1. Total Biaya

$$
\mathrm{TC}=\mathrm{TFC}+\mathrm{TVC}
$$

Keterangan :

TC $\quad=$ Biaya Total $($ Total Cost $)$

TFC $\quad=$ Total Biaya Tetap (Total Fixed Cost)

TVC = Total Biaya Variabel (Total Variable Cost)

2. Penerimaan

$$
\text { TR }(\text { Total Penerimaan })=Q \times P
$$

Keterangan :

TR = Total Penerimaan (Total Revenue) $\mathrm{Q}=$ Jumlah Produksi (Quantity)

$\mathrm{P} \quad \quad=$ Harga/Rupiah (Price)

3. Pendapatan

$$
\mathrm{TB}=\mathrm{TR}-\mathrm{TC}
$$

Keterangan :

TB = Total pendapatan yang diperoleh peternak (Total Benevit) $\mathrm{TR}=$ Penerimaan yang diperoleh peternak (Total Revenue)

TC = Biaya yang dikeluarkan peternak (Total Cost)

4. R/C Ratio

$$
\mathrm{R} / \mathrm{C} \text { Ratio }=\mathrm{TR} / \mathrm{TC}
$$

Keterangan:

$\mathrm{R} / \mathrm{C}$ Ratio = Efisiensi Biaya

TR = Total Revenue (Penerimaan)

TC $\quad=$ Total Biaya 


\section{Return on Investment (ROI) \\ ROI $=($ Keuntungan/Biaya Investasi $) \times 100 \%$}

\section{HASIL DAN PEMBAHASAN}

\section{Karakteristik Responden}

Rata-rata usia produktif peternak terbanyak yaitu pada umur 51-61 tahun yang memiliki prosentase $36,7 \%$ dari total responden dan yang paling sedikit sebanyak 3,3 \% dari total responden. Mayoritas pendidikan responden berada pada tingkat pendidikan sekolah menengah atas (SMA) sebanyak 16 orang dengan prosentase $53,4 \%$ sedangkan sekolah menengah pertama sebanyak 10 orang dengan prosentase 33,3 \%, tingkat Pendidikan sekolah dasar (SD) sebanyak 3 orang dengan prosentase $10 \%$ dan yang paling sedikit tingkat pendidikan sarjana (S1) sebanyak 1 orang dengan prosentase 3,3\%. Sebagian besar peternak ialah berjenis kelamin Laki-Laki sebanyak 29 orang dengan prosentase sebanyak 96,7 \% sedangkan responden perempuan sebanyak 1 orang dengan prosentase sebanyak 3,3\%.

Mayoritas responden memiliki tanggunggan keluarga 4-6 orang sebanyak 22 responden dengan prosentase sebesar $73,4 \%$. mayoritas responden mempunyai pengalaman beternak selama 1-10 tahun sebanyak 14 orang dengan prosentase $46,6 \%$ sedangkan responden yang memiliki beternak 11-20 tahun dan 21-30 tahun memiliki jumlah responden yang sama yaitu 8 orang dengan prosentase yang sama pula sebesar 26,7 \%. kepemilikan ternak mayoritas memiliki 100-600 ekor dengan jumlah responden 28 yang memiliki prosentase 93,3\% sedangkan jumlah ternak 7001200 dimiliki oleh 2 responden dengan prosentase sebesar 6,7 \%.

\section{Sistem Pemeliharaan Intensif}

Pemeliharaan itik petelur sistem intensif di Desa Kejapanan pemeliharaannya menggunakan teknik tambal sulam. tambal sulam yaitu menyeleksi itik produktif dan itik tidak produktif serta menjual itik yang dianggap tidak produktif, kemudian hasil penjualan itik afkir dibelikan kembali itik dara yang siap berproduksi. teknik tambal sulam yaitu mengecilkan biaya pakan yang disebabkan oleh itik tidak produktif. Keuntungan dari teknik tambal sulam yaitu dapat dinikmati setelah 1 bulan dijalankan karena itik dara yang di beli memerlukan adaptasi dan biasanya dapat berproduksi baik setelah 1 bulan berjalan.

Pakan yang digunakan oleh peternak itik pemeliharaan sistem intensif yaitu pakan buatan sendiri dengan campuran seperti: konsentrat, dedak, nasi aking, dan pakan tambahan seperti: kepala udang atau kupang. Bahan-bahan pakan tersebut di campur menjadi satu menggunakan sekop atau tangan dengan kebutuhan perhari/100 ekor yaitu kosentrat sebanyak $5 \mathrm{~kg}$, dedak $4 \mathrm{~kg}$, nasi aking 8 $\mathrm{kg}$, kepala udang $5 \mathrm{~kg}$ atau kupang $6 \mathrm{~kg}$. Pemberian pakan pada itik petelur sistem pemeliharaan intensif dilakukan sebanyak dua kali yaitu pada waktu pagi jam 06.00-0700 dan waktu sore pada jam 15.00-16.00. Untuk pengambilan telurnya dilakukan sebanyak satu kali yaitu pagi hari saat pemberian pakan. Jenis kandang yang digunakan peternak sistem pemeliharaan intensif yaitu kandang ranch dan kandang postal, namun rata-rata peternak menggunakan kandang jenis ranch. Dari jenis-jenis kandang tersebut ada milik sendiri dan kandang sewa dimana untuk penyewaan kandangnya sebesar Rp.30.000/bulan/50 ekor.

\section{Analisis Faktor-Faktor yang Mempengaruhi Pendapatan}

Faktor yang mempengaruhi pendapatan yaitu pakan, tenaga kerja, OVK, skala usaha, pengalaman dalam beternak, serta pendapatan yang diperoleh dari usaha peternakan itik sistem 
pemeliharaan intensif. Analisis pendapatan diperoleh dengan menghitung biaya produksi usaha. Gambaran biaya produksi usaha peternakan itik petelur sistem pemeliharaan intensif di Desa Kejapanan Kecamatan Gempol Kabupaten Pasuruan sebagai berikut:

\section{Biaya Tetap}

Biaya tetap merupakan nilai biaya yang besar kecilnya tidak tergantung produksi atau keseluruhan biaya-biaya yang nilai nya tetap yang dikeluarkan oleh peternak itik petelur. Biaya tetap terdiri dari biaya penyusutan kandang dan biaya penyusutan peralatan. Adapun hasil perhitungan disajikan pada Tabel 1.

Tabel 1. Biaya Tetap Usaha Peternakan Itik Petelur dengan Sistem Pemeliharaan Intensif di Desa Kejapanan Kecamatan Gempol Kabupaten Pasuruan

\begin{tabular}{|l|c|c|r|r|r|}
\hline No & $\begin{array}{c}\text { Jumlah Ternak } \\
\text { (ekor) }\end{array}$ & $\begin{array}{c}\text { Jumlah } \\
\text { Responden } \\
\text { (orang) }\end{array}$ & $\begin{array}{c}\text { Biaya } \\
\text { Penyusutan } \\
\text { Kandang/Bukan } \\
\text { (Rp) }\end{array}$ & $\begin{array}{c}\text { Biaya } \\
\text { Penyusuta } \\
\text { Perlatan/Bulan } \\
\text { (Rp) }\end{array}$ & $\begin{array}{c}\text { Total Biaya } \\
\text { Tetap }\end{array}$ \\
\hline 1 & 100 & 4 & $66.666,67$ & $6.550,00$ & $73.216,67$ \\
\hline 2 & 150 & 2 & $90.000,00$ & $8.633,33$ & $98.633,33$ \\
\hline 3 & 200 & 4 & $133.333,33$ & $10.716,67$ & $144.050,00$ \\
\hline 4 & 300 & 7 & $194.285,71$ & $15.133,33$ & $209.419,05$ \\
\hline 5 & 400 & 8 & $250.000,00$ & $20.183,39$ & $270.183,33$ \\
\hline 6 & 500 & 2 & $333.333,33$ & $26.766,67$ & $360.100,00$ \\
\hline 7 & 550 & 1 & $330.000,00$ & $31.766,67$ & $361.766,67$ \\
\hline 8 & 1000 & 1 & $666.666,67$ & $57.566,67$ & $724.233,33$ \\
\hline 9 & 1200 & 1 & $800.000,00$ & $66.533,33$ & $866.533,33$ \\
\hline
\end{tabular}

Rata-rata biaya penyusutan kandang paling rendah yang dikeluarkan oleh peternak sistem pemeliharaan intensif di Desa Kejapanan sebesar Rp. 66.666,67/Bulan sedangkan biaya ratarata penyusutan tertinggi yang dikeluarkan oleh peternak sebesar Rp. 800.000/Bulan. Penggunaan kandang peternak sistem pemeliharaan intensif yang ada di Desa Kejapanan Kecamatan Gempol Kabupaten Pasuruan ada 2 macam yaitu penggunaan kandang milik pribadi dan penggunaan kandang sewa, meskipun penggunaan kandang yang berbeda selisihnya tidak jauh berbeda. Biaya penyusutan kandang dan sewa kandang tidak dipengaruhi oleh jumlah produksi peternakan itik sistem pemeliharaan intensif. Hal ini sesuai apa yang di nyatakan oleh Rasyaf (2002), bahwa biaya tetap dalam usaha peternakan merupakan biaya tetap yang terlibat langsung dalam proses produksi ternak dan tidak memiliki perubahan meskipun ada perubahan jumlah hasil produksi yang dihasilkan dari usaha peternakan. Cara perhitungan untuk biaya penyusutan kandang yaitu dengan cara membagi biaya pembuatan kandang dan lama pemakaian kandang.

Rata-rata biaya penyusutan peralatan yang dikeluarkan oleh peternak itik petelur sistem pemeliharaan intensif di Desa Kejapanan Kecamatan Gempol Kabupaten Pasuruan yang paling rendah yaitu Rp. 6.550 sedangkan biaya penyusutan peralatan yang paling tinggi sebesar Rp. $66.533,33$. Perbedaan harga penyusutan disebabkan oleh jumlah dan harga peralatan yang berbedabeda dan juga dilihat dari besar kecilnya skala usaha yang dimiliki selain itu lama pemakaian peralatan yang digunakan oleh peternak itik petelur sistem pemeliharaan intensif juga mempengaruhi. 
Rata-rata biaya tetap yang dikeluarkan oleh peternak itik petelur sistem pemeliharaan intensif di Desa Kejapanan Kecamatan Gempol Kabupaten Pasuruan yang paling rendah sebesar Rp. 73.216,67 sedangkan biaya tetap tertinggi yang dikeluarkan oleh peternak itik petelur sistem pemeliharaan intensif sebesar Rp. 866.533,33. perbedaan total biaya tetap disebabkan oleh biaya penyusutan kandang dan biaya penyusutan peralatan yang berbeda. Hal ini sama dengan apa yang disampaikan oleh Yunus (2009) bahwa biaya tetap meliputi biaya penyusutan kandang dan biaya penyusutan peralatan yang memiliki arti tidak tergantung pada besar kecilnya skala usaha yang dimiliki.

\section{Biaya Variabel}

Biaya variabel merupakan jumlah biaya yang dikeluarkan oleh peternak yang jumlahnya dipengaruhi oleh besar kecilnya usaha, semakin besar barang yang dimiliki maka akan semakin besar biaya variabel yang dikeluarkan oleh peternak. Biaya variabel meliputi Biaya Ternak, Biaya OVK, Biaya Pakan, Biaya Transportasi, dan Biaya Tenaga Kerja. Biaya variabel tersebut akan mengalami peningkatan jika diiringi dengan peningkatan skala usaha yang dimiliki oleh peternak. Hasil perhitungan biaya variable disajikan pada Tabel 2.

Tabel 2. Biaya Variabel Usaha Ternak Itik Petelur Sistem Pemeliharaan Intensif di Desa

Kejapanan Kecamatan Gempol Kabupaten Pasuruan

\begin{tabular}{|c|c|c|c|c|r|r|r|r|}
\hline $\begin{array}{c}\mathrm{N} \\
\mathrm{o}\end{array}$ & $\begin{array}{c}\text { Jumlah } \\
\text { Terna } \\
\mathrm{k} \\
\text { (ekor) }\end{array}$ & $\begin{array}{c}\text { Jumlah } \\
\text { Responde } \\
\mathrm{n} \text { (orang) }\end{array}$ & $\begin{array}{c}\text { Benyusuta } \\
\mathrm{n} \text { Itik } \\
\text { Petelur } \\
\text { (Rp) }\end{array}$ & $\begin{array}{c}\text { Biaya } \\
\text { OVK/Bula } \\
\mathrm{n}(\mathrm{Rp})\end{array}$ & $\begin{array}{c}\text { Biaya } \\
\text { Pakan/Bula } \\
\mathrm{n}(\mathrm{Rp})\end{array}$ & $\begin{array}{c}\text { Biaya } \\
\text { Transportas } \\
\mathrm{i} \\
\text { /Bulan (Rp) }\end{array}$ & $\begin{array}{c}\text { Biaya } \\
\text { Tenaga } \\
\text { kerja/Bula } \\
\mathrm{n} \text { (Rp }\end{array}$ & $\begin{array}{c}\text { Total Biaya } \\
\text { Variabel/Bula } \\
\mathrm{n}(\mathrm{Rp})\end{array}$ \\
\hline 1 & 100 & 4 & 500.000 & 101.000 & 2.226 .000 & 38.500 & 357.449 & $3.222 .949,00$ \\
\hline 2 & 150 & 2 & 750.000 & 101.000 & 3.339 .000 & 38.500 & 536.173 & $4.764 .673,00$ \\
\hline 3 & 200 & 4 & 1.000 .000 & 101.000 & 4.452 .000 & 38.500 & 714.897 & $6.306 .397,00$ \\
\hline 4 & 300 & 7 & 1.500 .000 & 101.000 & 6.678 .000 & 38.500 & 1.072 .346 & $9.389 .846,00$ \\
\hline 5 & 400 & 8 & 2.000 .000 & 137.000 & 8.791 .410 & 53.900 & 1.429 .795 & $12.412 .105,00$ \\
\hline 6 & 500 & 2 & 2.500 .000 & 137.000 & 10.942 .350 & 69.300 & 1.787 .243 & $15.435 .893,00$ \\
\hline 7 & 550 & 1 & 2.750 .000 & 202.000 & 11.880 .150 & 77.000 & 1.965 .968 & $16.875 .118,00$ \\
\hline 8 & 1000 & 1 & 5.000 .000 & 238.000 & 22.260 .000 & 115.500 & 3.000 .000 & $30.613 .500,00$ \\
\hline 9 & 1200 & 1 & 6.000 .000 & 238.000 & 26.712 .000 & 115.500 & 4.500 .000 & $37.565 .500,00$ \\
\hline
\end{tabular}

Rata-rata biaya penyusutan peternakan itik petelur sistem pemeliharaan intensif di Desa Kejapanan Kecamatan Gempol Kabupaten Pasuruan yang paling rendah sebesar Rp. 500.000/bulan sedangkan biaya penyusutan ternak itik yang paling tinggi sebesar Rp. 6.000.000/bulan. Perbedaan biaya ternak itik dikarenakan jumlah ternak yang dimiliki, dimana semakin banyak jumlah ternak yang dimiliki maka semakin tinggi biaya penyusutan yang dikeluarkan oleh peternak itik petelur sistem pemeliharaan intensif di Desa Kejapanan Kecamatan Gempol Kabupaten Pasuruan.

Biaya OVK yang dikeluarkan oleh peternak itik sistem pemeliharaan intensif yang paling rendah yaitu sebesar Rp. 101.000 sedangkan biaya pengeluaran OVK yang paling tinggi sebesar Rp. 238.000. Jenis OVK yang diberikan yaitu: Turbo dan Fortevit. Penggunaan OVK dalam usaha ternak itik petelur sistem pemeliharaan intensif di Desa Kejapanan Kecamatan Gempol Kabupaten Pasuruan dilakukan berdasarkan pengalaman peternak karena peternak tidak secara rutin memberikan OVK ke ternak yang dipelihara dan hanya memberikan OVK ketika ternak dalam masalah seperti kurangnya nafsu makan atau produksi telur itik yang tidak stabil.

Biaya pakan yang dikeluarkan oleh peternak itik pemeliharaan intensif yang paling rendah sebesar Rp. 2.226.000 sedangkan biaya pakan paling tinggi yang dikeluarkan oleh peternak selama 
satu bulan sebesar Rp. 26.712.000. Biaya pakan yang dikeluarkan oleh peternak itik petelur sistem pemeliharaan intensif sangat bervariasi, karena semakin banyak ternak yang dimiliki maka semakin besar biaya pakan yang akan dikeluarkan. Pakan yang digunakan oleh peternak itik petelur sistem pemeliharaan intensif terdiri dari 3 macam formulasi ransum yaitu: konsentrat, dedak, bekatul dan pakan tambahan seperti kepala udang dan kupang.

Rata-rata biaya transportasi yang dikeluarkan oleh peternak itik petelur sistem pemeliharaan intensif yang paling rendah yaitu Rp. 38.500 sedangkan biaya transportasi yang paling tinggi dikeluarkan oleh peternak sebesar Rp. 115.500. Biaya transportasi yang dikeluarkan oleh peternak dipengaruhi oleh jarak dan jumlah pakan yang diangkut, semakin besar jumlah ternak yang dimiliki maka akan semakin besar biaya transportasinya hal ini sesuai dengan pernyataan Sudiyono (2004), yang menyatakan bahwa biaya transportasi dapat dilihat oleh dekat-jauhnya ebuah jarak, dimana semakin jauh jarak yang akan ditempuh maka semakin tinggi biaya transportasi yang akan dikeluarkan.

Biaya tenaga kerja yang dikeluarkan oleh setiap peternak itik petelur sistem pemeliharaan intensif yang paling rendah sebesar Rp. 357.449 sedangkan biaya tenaga kerja yang paling tinggi sebesar 4.500.000. Perbedaan upah tersebut dikarenakan perbedaan jumlah tenaga kerja dan skala usaha yang dimiliki. Biaya tenaga kerja terdiri dari biaya tunai dan tidak tunai, biaya tunai merupakan biaya tenaga kerja bayaran dan biaya tidak tunai merupakan biaya yang tidak dikeluarkan secara langung. Biaya tenaga kerja tunai dihitung berdasarkan upah tenaga kerja yang ditentukan oleh pemilik ternak sedangkan biaya tenaga kerja keluarga dihitung berdasarkan upah tenaga kerja. Hal ini sesuai dengan pernyataan Sinaga, Lubis, \& Butar (2011) yang berpendapat bahwa tenaga kerja yang digunakan oleh peternak dibagi menjadi dua yaitu tenaga kerja keluarga dan tenaga kerja dari luar keluarga (upahan).

Rata-rata total biaya variabel yang dikeluarkan oleh peternak itik petelur sistem pemeliharaan intensif yang terendah sebesar Rp. 3.222 .949 sedangkan total biaya variabel yang tertinggi sebesar Rp. 37.565.500,00. Perbedaan total biaya variabel ini dikarenakan perbedaan jumlah ternak yang dipelihara oleh masing-masing peternak. Semakin banyak ternak yang dimiliki maka akan semakin meningkat biaya variabelnya. Hal ini sesuai dengan pernyataan Sudiyono (2004) yang berpendapat bahwa semakin besar output yang didapatkan maka semakin besar biaya variabel yang akan dikeluarkan oleh pelaku usaha.

Rata-rata total biaya peternakan itik petelur sistem pemeliharaan intensif yang terdiri dari biaya tetap dengan biaya variabel yang terendah sebesar Rp 3.296.165,67 sedangkan total biaya yang tertinggi sebesar Rp. 38.432.033,33. Perbedaan ini disebabkan karena besarnya biaya tetap dan biaya variabel yang dikeluarkan oleh setiap peternak itik petelur sistem pemeliharaan intensif. Semakin banyak biaya tetap dan biaya variabel maka akan semakin banyak total biaya yang dikeluarkan. Hal ini sesuai dengan pernyataan Sudiyono (2004) bahwa biaya total merupakan hasil dari penjumlahan dari biaya tetap dan biaya variabel.

\section{Penerimaan Peternakan Usaha Itik Petelur Sistem Pemeliharaan Intensif di Desa Kejapanan Kecamatan Gempol Kabupaten Pasuruan}

Penerimaan merupakan total hasil yang diperoleh peternak dari hasil pemeliharaan itik petelur selama satu bulan. Penerimaan peternak itik petelur yang diperoleh digunakan untuk menutupi biaya total yang telah dikeluarkan. Usaha itik petelur sistem pemeliharaan intensif sangat perlu dilakukan efisiensi biaya untuk meningkatkan pendapatan dengan hasil yang maksimal. Pendapatan merupakan hasil selisih perhitungan antara penerimaan dengan biaya total. Apabila nilai pendapatan yang diperoleh positif maka usaha tersebut akan memperoleh keuntungan dan jika nilai pendapatan yang diperoleh negatif maka usaha tersebut akan mengalami kerugian. Adapun rata-rata 
penerimaan yang diterima oleh peternak itik petelur sistem pemeliharaan intensif disajikan pada Tabel 3.

Rata-rata penerimaan yang diperoleh dari hasil ternak (telur) oleh peternak itik petelur sistem pemeliharaan intensif yang paling rendah sebesar Rp 3.563.625 sedangkan penerimaan peternak itik petelur yang paling tinggi sebesar $\mathrm{Rp}$ 42.994.700. Perbedaan total penerimaan yang diterima oleh peternak disebabkan oleh jumlah penjualan telur itik dan harga telur itik yang berbeda. Hal ini sesuai dengan pernyataan Sinaga, Lubis, \& Butar (2011) bahwa penerimaan yaitu hasil perhitungan melalui perkalian dari produksi total dengan harga satuan barang.

Tabel 3. Penerimaan Peternakan Usaha Itik Petelur Sistem Pemeliharaan Intensif di Desa Kejapanan Kecamatan Gempol Kabupaten Pasuruan

\begin{tabular}{|l|c|r|r|r|}
\hline No & $\begin{array}{c}\text { Jumlah Ternak } \\
\text { (ekor) }\end{array}$ & $\begin{array}{c}\text { Jumlah Responden } \\
\text { (orang) }\end{array}$ & $\begin{array}{c}\text { Total Penerimaan } \\
\text { /Bulan (Rp }\end{array}$ & \multicolumn{1}{c|}{$\begin{array}{c}\text { Total Pendapatan } \\
\text { /Bulan (Rp) }\end{array}$} \\
\hline 1 & 100 & 4 & 3.563 .625 & $267.459,33$ \\
\hline 2 & 150 & 2 & 5.147 .200 & $283.893,67$ \\
\hline 3 & 200 & 4 & $11.142 .785,71$ & $1.543 .520,67$ \\
\hline 4 & 300 & 7 & $14.377 .687,5$ & $1.695 .399,17$ \\
\hline 5 & 400 & 8 & 18.770 .400 & $2.974 .407,00$ \\
\hline 6 & 500 & 2 & 23.961 .750 & $6.724 .865,33$ \\
\hline 7 & 550 & 1 & 38.919 .600 & $7.581 .866,67$ \\
\hline 8 & 1000 & 1 & 42.994 .700 & $4.562 .666,67$ \\
\hline 9 & 1200 & 1 & & \\
\hline
\end{tabular}

Rata-rata pendapatan peternak itik petelur sistem pemeliharaan intensif yang paling rendah sebesar Rp. 267.459,33 sedangkan pendapatan yang terbesar yaitu Rp. 7.581.866,67. Hal ini disebabkan karena perbedaan biaya yang dikeluarkan oleh peternak dengan penerimaan yang didapatkan oleh peternak itik petelur sistem pemeliharaan intensif. Pendapatan yang didapatkan oleh peternak merupakan selisih antara penerimaan dengan biaya yang dikeluarkan. Hal ini sesuai dengan pendapat Rasyaf (2002), bahwa besarnya pendapatan dari usaha ternak itik yaitu untuk mengukur dan mengetahui seberapa besar pendapatan usaha peternakan itik yang mampu mencapai keberhasilan yang maksimal. Pendapatan merupakan hasil keuntungan bersih yang diterima oleh peternak sistem pemeliharaan intensif.

\section{Analisis Efisiensi}

Suatu usaha peternakan itik sistem pemeliharaan intensif akan dikatakan efisien apabila usaha ternak telah mampu menggunakan sumber dana yang dimiliki sebaik mungkin untuk melengkapi kebutuhan usahanya. Sehingga usaha peternakan itik petelur sistem pemeliharaan intensif di Desa Kejapanan Kecamatan Gempol Kabupaten Pasuruan untuk mengetahui imbangan penerimaan total dan biaya total Tabel 4 .

$\mathrm{R} / \mathrm{C}$ ratio yang paling rendah sebesar 1,06 $>1$ dengan skala usaha 150 hal ini menunjukkan bahwa hasil usaha tersebut efisien atau menguntungkan dengan arti setiap mengeluarkan 100 rupiah bisa menghasilkan 118 rupiah sedangkan $\mathrm{R} / \mathrm{C}$ yang paling tinggi sebesar 1,39 > 1 dengan skala usaha sebesar 550 hal ini menunjukkan bahwa setiap mengeluarkan 100 rupiah bisa menghasilkan 139 rupiah. Hal ini searah dengan penelitian terdahulu seperti yang dilakukan oleh Sinaga, Lubis, \& Butar (2011) bahwa nilai R/C ratio pada penelitianya sebesar 1,31 yang memiliki arti usaha pada penelitian tersebut dikatakan layak untuk berdiri dan dikembangkan secara ekonomis. Perbedaan R/C Ratio yang diperoleh peternak disebabkan oleh total penerimaan dan total biaya yang berbeda. Pengembalian atas investasi Return on Investmen (ROI) merupakan perbandingan antara pemasukan 
(income) per tahun terhadap dana investasi yang memberikan indikasi profitabilitas suatu investasi, Suharno (2002). Rata-rata ROI paling rendah sebesar $5.8 \%$ dengan skala usaha 150 sedangkan yang paling tinggi sebesar 39,01 \%. Perbedaan prosentase ROI disebabkan karena perbandingan keuntungan dengan biaya investasi yang berbeda.

Tabel 4. Analisis Efisiensi Usaha Peternakan Itik Sistem Pemeliharaan Intensif di Desa Kejapanan Kecamatan Gempol Kabupaten Pasuruan

\begin{tabular}{|l|c|c|c|c|}
\hline No & $\begin{array}{c}\text { Jumlah Ternak } \\
\text { (ekor) }\end{array}$ & Jumlah Responden (orang) & R/C Ratio & ROI (\%) \\
\hline 1 & 100 & 4 & 1,08 & 8,12 \\
\hline 2 & 150 & 2 & 1,06 & 5,83 \\
\hline 3 & 200 & 4 & 1,13 & 13,27 \\
\hline 4 & 300 & 7 & 1,16 & 13,39 \\
\hline 5 & 400 & 8 & 1,13 & 18,84 \\
\hline 6 & 500 & 2 & 1,19 & 24,01 \\
\hline 7 & 550 & 1 & 1,39 & 11,87 \\
\hline 8 & 1000 & 1 & 1,24 & 1,12 \\
\hline 9 & 1200 & 1 & & \\
\hline
\end{tabular}

\section{KESIMPULAN}

Berdasarkan hasil penelitian analisis pendapatan peternakan itik petelur sistem pemeliharaan intensif di Desa Kejapanan Kecamatan Gempol Kabupaten Pasuruan dapat disimpulkan bahwa :

1. Pendapatan peternakan itik petelur sistem pemeliharaan intensif di Desa Kejapanan Kecamatan Gempol Kabupaten Pasuruan yang terkecil diperoleh oleh peternak yang mempunyai skala usaha 100 ekor senilai Rp. 267.459/Bulan sedangkan pendapatan terbesar diperoleh oleh peternak dengan skala usaha 1000 ekor senilai Rp. 7.581.866/Bulan.

2. R/C ratio peternakan itik petelur sistem pemeliharaan intensif di Desa Kejapanan Kecamatan Gempol Kabupaten Pasuruan yang terendah yaitu 1,06 dengan skala usaha sebesar 150 ekor sedangkan yang tertinggi yaitu 1,39 dengan skala usaha sebesar 550 ekor.

3. Return on Investment (ROI) peternakan itik petelur sistem pemeliharaan intensif di Desa Kejapanan Kecamatan Gempol Kabupaten Pasuruan yang terendah yaitu 5,8 \% dengan skala usaha 150 ekor sedangkan yang tertinggi yaitu 39,01\% dengan skala usaha 550 ekor.

\section{DAFTAR PUSTAKA}

Ditjen PKH. (2017). Statistik Peternakan dan Kesehatan Hewan 2017. Jakarta: Direktorat Jendral Peternakan. Departemen Pertanian RI.

Prasetyo. L.H., P. P. Ketaren \& T. Susanti. (2010). Panduan Budidaya dan Usaha Ternak Itik. Bogor:

Balai Penelitian Ternak.

Rasyaf, M. (2002). Beternak Itik. Edisi Ke-16. Yogyakarta: Kanisius.

Sinaga, R. S. N Lubis. \& H. Butar. (2011). Analisis Usaha Ternak Itik Petelur di Kecamatan Bandar Khalifah Kabupaten Serdang Begadai. Medan: Depertemen Agribisnis Fakultas Pertanian Universitas Sumatera Utara.

Sudiyono, A. (2004). Pemasaran Pertanian. Malang: Universitas Muhammadiyah Malang.

Suharno, B S. (2002). Beternak Itik di Kandang Baterai. Jakarta: Penebar Swadaya.

Yunus. (2009). Analisis Efisiensi Produksi Usaha Peternakan Ayam Ras Pedaging Pola Kemitraan dan Mandiri di Kota Palu Provinsi Sulawesi Tengah. Semarang: Program Pascasarjana. Universitas Diponegoro. 